\title{
UPAYA MENINGKATKAN HASIL BELAJAR KELAS VII.3 SMP N 42 PADANG DALAM PEMBELAJARAN PKN MELALUI CARA MENCATAT DENGAN TEKNIK PETA PIKIRAN (MIND MAPPING)
}

\author{
Harlina Eka Suyandi \\ SMPN 42 Padang
}

\section{Abstrak}

Salah satu bagian dari proses pembelajaran yang cukup penting bagi kemajuan belajar adalah membuat catatan, yaitu catatan yang dapat dibaca dan dimengerti bagi si pembaca catatan (Vos, dalam Anwar 2000:165). Penelitian ini menitikberatkan pada adanya proses perbaikan dan perubahan secara terus menerus yang dilaksanakan secara bersiklus. Metode penelitian yang dipakai adalah penelitian tindakan kelas. Menurut pengamatan penulis ada hubungan antara kualitas catatan dengan kemampuan peserta didik. Peserta didik yang berhasil 5 besar di kelas mempunyai catatan yang lengkap, bagus dan rapi. Kualitas catatan yang baik merupakan jembatan untuk meraih keberhasilan. Dengan adanya catatan siswa yang bagus dan rapi akan dapat memotivasi peserta didik belajar lebih baik.

\section{Keywords: Belajar, mind mapping,}

\section{PENDAHULUAN}

Proses mencatat merupakan bagian dari aktivitas belajar sehingga jika di dalam proses pembelajaran peserta didik aktif mencatat maka aktivitas belajar peserta didik meningkat dan hasil belajar pun akan lebih optimal. Tujuan membuat catatan antara lain, (1) untuk menyimpulkan ide argumen -argumen (to summary a ideas and argumen), (2) untuk memilih bagian-bagian yang relevan ( to select relevan points), (3) membantu peserta didik mendalami materi ajar (to digest the material) dan (4) untuk memperjelas pemahaman tentang topik-topik ( to clasify the understanding at the topic) (http://www. Ghslibrary.webfront.net). Penulis mengamati banyak sekali catatan peserta didik yang dibuat seadanya, tidak lengkap, tidak jelas, tidak teratur dan tidak tertata rapi. Dari 29 peserta didik kela 7.3 SMPN 42 Padang sebanyak 20 orang $(68,96 \%)$ peserta didik mempunyai catatan seadanya berarti hampir $(70 \%)$ perlu di beri pengetahuan tentang teknik mencatat yang baik dan mudah dipahami.Malahan ada sebagian peserta didik tidak mempunyai catatan sama sekali. 
82 |Upaya meningkatkan hasil..

Menurut pengamatan peneliti rendahnya kualitas catatan bermuara pada hasil belajar kelas VII.3 SMPN 42 Padang pada pelajaran PKN. Ini disebabkan oleh beberapa faktor sebagai berikut:

1. Kurangnya kemauan siswa dalam belajar

2. Kurangnya kemampuan siswa dalam mencatat penjelasan guru

3. Banyaknya alasan siswa disaat disuruh mencatat antara lain pena macet atau hilang, catatan jauh tertinggal

4. Catatan yang sering ketinggalan dirumah

5. Mudah lupa dengan apa yang diingat sebelumnya

6. Tidak mengerti apa yang mau dicatat

7. Guru tidak berkesempatan mengontrol catatan siswa

Untuk mengatasi permasalahan diatas Penulis akan menerapkan tekhnik Mind Mapping yang merupakan salah satu cara mencatat materi pelajaran yang memudahkan siswa dalam belajar. Mind Mapping merupakan cara untuk mencatat yang kreatif dengan menggunakan warna-warna dan gambar yang menarik Selain itu, adanya kombinasi warna, simbol, bentuk, dan sebagainya memudahkan otak untuk menyerap informasi yang diterima serta menumbuhkan rasa ingin tahu lebih banyak bagi peserta didik. Materi yang padat juga merupakan salah satu penyebab rendahnya hasil belajar PKn. Kemampuan peserta didik untuk memahami materi pelajaran sangat rendah karena SMPN 42 Padang merupakan sekolah bina lingkungan yang baru berdiri Tahun 2017/2018. Peserta didik berasal dari lingkungan sekitar sekolah tanpa mempertimbangkan Nilai Evaluasi Murni. Untuk itu dalam PTK ini peneliti mengambil judul “ Upaya meningkatkan hasil belajar Kelas VII.3 SMP N 42 Padang dalam pembelajaran PKN melalui Cara Mencatat dengan Teknik Peta Pikiran (Mind Mapping)".

\section{Hakekat belajar}

Belajar merupakan upaya yang dilakukan untuk mengetahui sesuatu yang baru sehingga akan timbul perubahan kearah yang baik sebagai hasil dari pengalamannya sendiri dalam interaksinya dengan lingkungan. Hal ini sejalan dengan pengertian belajar yang dikemukakan oleh Prayitno (2008:310). Kegiatan belajar merupakan hal penting yang paling pokok dalam keseluruhan proses pendidikan. Hal itu mengandung arti bahwa berhasil tidaknya pencapaian tujuan pendidikan banyak bergantung kepada bagaimana proses belajar mengajar yang dialami oleh siswa. Asri Budiningsih (2004:20) menyatakan bahwa menurut teori behavioristik, belajar adalah perubahan tingkah laku sebagai akibat dari adanya interaksi antara stimulus dan respon. Seseorang dianggap telah belajar sesuatu jika ia dapat menunjukkan perubahan tingkah lakunya. Menurut teori kontruktivisme, belajar adalah suatu proses pembentukan pengetahuan oleh 
peserta didik agar aktif melakukan kegiatan, aktif berfikir, menyusun konsep, dan member makna tentang hal-hal yang sedang dipelajarinya.

Wina Sanjaya (2006: 57) menyatakan bahwa belajar dianggap sebagai proses perubahan perilaku sebagai akibat dari pengalaman dan latihan. Hilgard mengungkapkan "Learning is the process by wich an activity originates or canges or changed through training procedurs (weather in the laboratory or in the naural environment). Bagi Hilgard belajar adalah proses perubahan melalui kegiatan atau prosedur latihan baik latihan di dalam laboratorium maupun dalam lingkungan alamiah. Dari uraian di atas, kata kunci dari defenisi belajar adalah perubahan tingkah laku kearah yang lebih baik. Perubahan yang disadari sehingga mengakibatkan bertambahnya pengetahuan, sikap, ketrampilan yang diperoleh dari interaksi individu dan lingkungannya.

1. Hasil Belajar

Hasil belajar merupakan akibat dari belajar. Dengan belajar manusia melakukan perubahan - perubahan kualitatif, sehingga tingkah lakunya berkembang. Berkaitan dengan hasil belajar. Sudjana (1999) menyatakan bahwa ' hasil belajar adalah kemampuan - kemampuan yang dimiliki siswa setelah menerima pengalaman belajar. Selanjutnya menurut Hamalik (2008) hasil belajar adalah sebagai terjadinya perubahan tingkah laku pada diri seseorang yang dapat di amati dan di ukur bentuk pengetahuan, sikap dan ketrampilan. Perubahan tersebut biasa diartikan sebagai terjadinya peningkatan dan pengembangan yang lebih baik dari sebelumnya yang tidak tahu menjadi tahu.

Selanjutnya Bloom (1996) membagi hasil belajar pada tiga ranah yaitu; ranah kognitif, ranah afektif dan ranah psikomotorik. Ranah kognitif terbagi dari enam tingkat, yaitu pengetahuan, menulis, pemahaman (understand), penerapan (apply), analisa (analyze), evaluasi (evaluance), dan daya cipta (create). Hasil belajar merupakan akhir dari sebuah proses pembelajaran dan ditunjukkan dengan perubahan dalam intelektual dan sikap siswa. Hasil belajar juga ditandai dengan perubahan dalam intelektual dan sikap siswa. Hasil belajar merupakan hasil yang diperoleh setelah proses pembelajaran maupun perubahan tingkah laku dan sikap siswa yang telah mengalami belajar. Hasil belajar dapat menjadi tolak ukur untuk menentukan tingkat keberhasilan siswa dalam penguasaan konsep dan pemahaman konsep.

\section{Peta Pikiran (Mind Mapping)}

Mind mapping diciptakan pertama kali oleh Tony Buzan dari Inggris, seorang pakar pengembangan otak, kreativitas dan revolusi pendidikan sejak awal tahun 1970'an. Mind mapping merupakan sistem belajar dan berpikir yang paling banyak digunakan di seluruh dunia. Mind mapping merupakan sistem belajar dan berpikir menggunakan kedua belah otak, menggunakan otak sesuai dengan cara kerja alaminya, mengeluarkan seluruh potensi dan kapasitas otak penggunanya yang masih tersembunyi, 
mencerminkan apa yang terjadi secara internal di dalam otak kita saat belajar dan berpikir, mencerminkan secara visual apa yang terjadi pada otak saat belajar dan berpikir. (Keliat \& Hastuti,2017).

Mind mapping merupakan cara mencatat yang kreatif dan efektif bagi siswa untuk menempatkan informasi ke dalam otak dan mengambil informasi ke luar dari otak (Ristiasari, 2012). Mencatat dengan tekhnik Mind mapping, seseorang akan mudah mengasumsikan ide - ide orisinilnya kemudian memacu ide - ide baru. Busan dalam Porter dan Hernacki (2003: 165 - 167) merinci cara/ langkah- langkah membuat peta pikiran dalam buku catatan. Langkah-langkah yang dimaksud yaitu:

A. Buatlah lingkaran di tengah kertas, dan di dalam lingkaran itu ditulis dengan gagasan utama yang sedang dibicarakan.

B. Tambahkan sebuah cabang pada sisa lingkaran untuk tiap poin kunci dari gagasan utama (dianjurkan menggunakan pensil/ balpoin warna-warni).

C. Tulis kata kunci pada setiap cabang dari gagasan utama.

D. Tuliskan gagasan penting pada setiap cabang.

E. Gunakan bentuk acak untuk gagasan lain.

F. Buat huruf yang mengesankan (nuansa berbeda) misalnya kotak kotak, tulisan cetak tebal, digarisbawahi, cetak miring, pewarnaan dan sebagainya.

Selain dikemukakan Busan di atas, Svantenson dan Vos membuat peta pikiran yang baik antara lain:

A. Bayangkan bahwa sel-sel otak anda seperti pohon. Masing-masing menyimpan informasi yang menghubungkan pada cabng-cabangnya.

B. Susun poin-poin kunci dari topik manapun.

C. Buat simbol utama di tengah halaman lalu gambar cabang-cabangnya menyebar di sekelilingnya.

D. Catatan hanya satu kata untuk setiap symbol

E. Letakkan poin yang berhubungan pada cabang yang sama

F. Buat simbol yang berbeda untuk maksud yang berbeda (Vos, 2002:165-167).

\section{Pengertian PKN}

PKN adalah salah satu mata pelajaran yang diajarkan untuk jenjang SMP/MTs, dirancang untuk menghasilkan siswa yang memiliki keimanan dan akhlak mulia sebagimana diarahkan oleh falsafah hidup bangsa Indonesia yaitu Pancasila sehingga dapat berperan sebagai warganegara yang efektif dan bertanggung jawab. (Rustopo dan Muchson, 2014: iii ). Secara umum tujuan mata pelajaran PKN pada jenjang pendidikan dasar dan menengah adalah mengembangkan potensi peserta didik dalam seluruh dimensi kewarganegaraan, yakni : (1) sikap kewarganegaraan termasuk keteguhan, komitmen, dan tanggung jawab kewarganegaraan (civic confidence, civic committment, and civic responsibility); (2) pengetahuan kewarganegaraan (civic knowledge); (3) keterampilan kewarganegaraan 
termasuk kecakapan dan partisipasi kewarganegaraan (civic competence and civic responsibility).

Secara khusus tujuan mata pelajaran PKN yang berisikan keseluruhan dimensi tersebut sehingga peserta didik mampu :

A. menampilkan karakter yang mencerminkan penghayatan, pemahaman, dan pengamalan nilai dan moral Pancasila secara personal dan sosial;

B. memiliki komitmen konstitusional yang ditopang oleh sikap positif dan pemahaman utuh tentang Undang-Undang Dasar Negara Republik Indonesia Tahun 1945;

C. berpikir secara kritis, rasional, dan kreatif serta memiliki semangat kebangsaan dan cinta tanah air yang dijiwai oleh nilai-nilai Pancasila, Undang-Undang Dasar Negara Republik Indonesia Tahun 1945, semangat Bhinneka Tunggal Ika, dan komitmen Negara Kesatuan Republik Indonesia.

D. berpartisipasi secara aktif, cerdas, dan bertanggung jawab sebagai anggota masyarakat, tunas bangsa, dan warga negara sesuai dengan harkat dan martabatnya sebagai makhluk ciptaan Tuhan Yang Maha Esa yang hidup bersama dalam berbagai tatanan sosial kultural.

Berdasarkan pemikiran di atas, jelas bahwa mata pelajaran PKn merupakan mata pelajaran yang membentuk karakter peserta didik sesuai dengan nilai-nilai budaya bangsa, yang memiliki karakter bangsa, sekaligus untuk menumbuhkan semangat nasionalisme peserta didik.

\section{METODOLOGI PENELITIAN}

Sesuai dengan latar belakang masalah, rumusan masalah dan pemecahan masalah, metode penelitian yang dipakai adalah penelitian tindakan kelas. Penelitian ini menitikberatkan pada adanya proses perbaikan dan perubahan secara terus menerus yang dilaksanakan secara bersiklus. Penelitian yang dilaksanakan menggunakan siklus yang terdiri dari empat bahagian yaitu rencana, tindakan pengamatan, atau observasi dan refleksi pelaksaan penelitian terdiri dari dua aspek yaitu persentase dan hasil belajar siswa akhir siklus I dan II.(Kemis:2004)

Lebih lanjut menurut Sukmadinata ( 2005:140), PTK merupakan suatu perencanaan sistematika yang dilaksanakan oleh para pelaksana dalam kegiatanya sendiri (dalam pendidikan dilakukan oleh guru, dosen, kepala sekolah, konselor) dalam mengumpulkan data tentang pelaksanaan kegiatan, keberhasilan dan hambatan yang dihadapi, untuk kemudian menyusun rencana dan melakukan kegiatan penyempurnaan PTK berkaitan dengan penelitian kualitatif, karena dalam pengumpulan datanya menggunakan pendekatan kualitatif. Penelitian dilakukan di SMP N 42 Padang tahun ajaran 2017/2018 dengan alamat Jalan Pasia Jambak Pasia Nan Tigo. Kecamatan Koto Tangah Kota .Peserta didik yang berjumlah 29 
orang yang terdiri dari laki - laki 14 Orang dan perempuan 15 orang. SMPN 42 Padang merupakan sekolah baru didirikan yang merupakan filial dari SMPN 34 Padang. Peserta didik yang masuk merupakan siswa yang berasal dari daerah sekitar sekolah yang tidak dijaring melalui sistem online sebagaimana yang dilakukan terhadap sekolah lain.

Selain kemampuan akademis yang rendah peserta didik juga mempunyai latar belakang ekonomi lemah, kesadaran untuk belajar sangat kurang.dan kemauan belajar sangat rendah sehingga dalam belajar peserta didik lebih banyak melakukan aktifitas yang tidak sesuai dengan pembelajaran.Begitu juga dengan catatan materi pelajaran nyaris tidak mereka punyai. Walaupun ada, catatan mereka seadanya dan acak-acakan Sebahagian kecil peserta didik yang memiliki catatan yang lengkap dan rapi.. Penelitian ini dilaksanakan selama 4 bulan mulai dari Januari sampai dengan Mei 2018.

\section{HASIL DAN PEMBAHASAN}

\section{A. Pra Siklus}

Pada bagian ini Penulis akan memaparkan data riil tentang rendahnya hasil belajar dari peserta didik kelas 7.3 SMPN 42 Padang sebelum tindakan dilakukan. Data ini dikumpul melalui dokumen berupa daftar nilai peserta didik, daftar hadir dan tugas.

Untuk lebih jelasnya bisa dilihat dari tabel berikut:

Tabel 1. Kualitas Catatan Kondisi Awal di kelas VII.3 SMP N 42 Padang

\begin{tabular}{|c|c|c|}
\hline Kriteria kualitas & Jumlah peserta didik & $\%$ \\
\hline Sangat Baik & 2 & 7 \\
\hline Baik & 3 & 10 \\
\hline Sedang & 6 & 20 \\
\hline Kurang & 18 & 70 \\
\hline
\end{tabular}

Tabel 2. Nilai Awal peserta didik SMPN 42 Padang

\begin{tabular}{|l|l|l|l|l|l|l|}
\hline JENIS KELAMIN & \multicolumn{5}{|c|}{ PEROLEHAN HASIL BELAJAR } \\
\hline \multirow{2}{*}{ JENIS KELAMIN } & $<$ KKM & & KKM & & >KKM & \\
\cline { 2 - 8 } & JML & $\%$ & JML & $\%$ & JML & $\%$ \\
\hline 14 orang laki2 & 9 & 31 & 3 & 10 & 2 & 8 \\
\hline 15 Perempuan & 9 & 31 & 3 & 10 & 3 & 10 \\
\hline Jumlah & 18 & 62 & 6 & 20 & 5 & 18 \\
\hline
\end{tabular}

Berdasarkan tabel diatas dapat disimpulkan bahwa:

1. Kecil dari KKM, dari tabel diatas diketahui bahwa jumlah peserta didik laki2 sebanyak 14 orang, ternyata 9 dibawah KKM dengan prosentase $31 \%$ sedangkan peserta didik perempuan dari 15 orang ternyata 9 orang berada dibawah KKM dengan 
prosentase $31 \%$. Ternyata kemampuan peserta didik perempuan sama dengan laki-laki.

2. Sama dengan KKM diketahui dari tabel diatas jumlah peserta didik laki-laki dan perempuan sebanyak 3 orang sama dengan KKM dengan prosentase $10 \%$.

3. Diatas dari KKM diketahui dari tabel diatas jumlah peserta didik laki-laki orang dengan prosentase $8 \%$ sedangkan pesrta didik perempuan 3 orang dengan prosentase $10 \%$

B. Siklus 1

1. Perencanaan

Pada bagian perencanaan ini Penulis mempersiapkan RPP, bahan ajar, Media , soal .

Dalam tahap perencanaan kegiatan yang dilakukan antara lain:

A. Menyusun rencana pelajaran (RPP)

B. Menyiapkan peta pikiran (bagan)

C. Menyiapkan instrument seperti menentukan kriteria kuliatas catatan siswa

D. Menyiapkan soal ujian akhir siklus

2. Tindakan

Pada bagian tindakan mencakup 4 kali pertemuan, masing-masing pertemuan terdiri dari:

A. Pendahuluan

B. Kegiatan inti

C. Penutup

Kegiatan yang dilakukan adalah melaksanakan PBM bersama mitra sebagai kolaborator. Secara rinci kegiatan yang dilaksanakan adalah sebagai berikut:

A. Pendahuluan

1). Guru melaksanakan appersepsi tentang materi ajar Perlindungan dan Penegakan HAM di Indonesia dengan meminta siswa menceritakan peristiwa pelanggaran HAM yang diketahuinya.

2). Guru mitra mengamati proses pelajaran yang sedang berlangsung dengan mengisi lembaran pengamatan untuk siswa dan lembaran pengamatan untuk guru

3). Peserta didik ditugaskan untuk mempersiapkan buku catatan dan buku sumber yang berkenaan dengan materi pembelajaran

4). Guru menyampaikan orientasi umum tentang materi dan manfaat dari mempelajari materi Hak Asasi Manusia

5) Guru menyampaikan tujuan pembelajaran tentang Materi Hak Asasi Manusia

6) Peserta didik diberi informasi dan teknik mencatat menggunakan Mind mapping 
B. Kegiatan Inti

1) Guru menayangkan gambar tentang peristiwa pelanggaran HAM di Indonesia

2) Peserta didik mengamati gambar yang diperlihatkan guru

3) Peserta didik diberi kesempatan untuk bertanya tentang gambar yang telah diperlihatkan sesuai dengan materi pembelajaran

4) Guru memberikan contoh tentang cara mencatat dengan tekhnik mind mapping

5) Peserta didik diminta mencatat materi berdasarkan konsep peta pikiran

6) Peserta didik diminta membuat lingkaran di tengah kertas dan di dalam lingkaran ditulis gagasan utama yang sedang dibicarakan

7) Peserta didik diminta menambahkan sebuah cabang pada sisi lingkaran untuk tiap point kunci dari gagasan utama dianjurkan menggunakan pensil/balpoin warna - warni

8) Peserta didik diminta menulis kata kunci pada setiap cabang dari gagasan utama

9) Peserta didik diminta menulis gagasan penting pada setiap cabang.

10) Peserta didik diminta membuat cabang pada setiap cabang dengan membaca materi pembelajaran kiri kanan secara seimbang

11) Setiap cabang diberi warna berbeda

12) Guru membimbing peserta didik mencari kata-kata kunci dari materi pelajaran

13) Peserta didik yang mampu dan mau menjelaskan pada teman-temannya mind mapping yang telah dibuat

14) Peserta didik lain menanggapi materi yang telah dijelaskan

\section{Pengamatan}

Pengamatan dalam penelitian ini dilakukan oleh teman sejawat yang mengajar mata pelajaran IPS. Pada tahap observasi, guru bersama teman kolaborator mengamati tingkah laku peserta didik. Pengamatan ditujukan untuk memperoleh data tentang apakah peserta didik membuat peta pikiran ketika mencatat materi pelajaran. Kalau ada seberapa banyak yang melakukanya, apakah membuat kesimpulan di akhir proses pembelajaran. Apakah peserta didik merasa terbantu. Kalau ya, seberapa banyak, apakah peserta didik merasa catatan lebih lengkap dan mudah dipahami. Kalau ya seberapa banyak. Dan apakah peserta didik memahami semua materi yang diberikan kalau ya seberapa banyak.

4. Refleksi 
Pada tahap ini guru bersama teman kolaborator berdialog mendiskusikan hasil pengamatan, megevaluasi keberhasilan yang dicapai dan permasalahan ditemui dalam siklus 1 . Hasil refleksi itu dijadikan sebagai dasar/ landasan untuk memperbaiki kelamahan kelemahan yang masih ditemui. Rencana perbaikan dijadikan sebagai dasar untuk melakukan tindakan pada siklus berikutnya (siklus II). Keberhasilan tindakan dapat diketahui konteks catatan yang dibuat peserta didik. Kualitas catatan dilihat dari beberapa kriteria melalui rubrik pensekoran (scoring) rubriks sebagaimana tabel berikut ini.

Tabel 3. Rubrik skor (scoring rubriks) untuk menetukan kualitas catatan peserta didik.

\begin{tabular}{|c|c|c|c|}
\hline No & $\begin{array}{l}\text { Kriteria } \\
\text { Kualitas }\end{array}$ & Catatan peserta didik & Keterangan \\
\hline 1 & Sangat baik & $\begin{array}{l}\text { Peta pikiran sangat baik, logis, } \\
\text { dan dapat dipahami, materi } \\
\text { catatan lengkap, tulisan sangat } \\
\text { jelas, dapat dibaca, mengandung } \\
\text { kemudahan }\end{array}$ & \\
\hline 2 & Baik & $\begin{array}{l}\text { Peta pikiran lengkap, logis dan } \\
\text { dapat dipahami, materi yang } \\
\text { dicata lengkap, tulisan jelas/ } \\
\text { dapat dibaca, indah }\end{array}$ & \\
\hline 3 & Sedang & $\begin{array}{l}\text { Peta pikiran cukup lengkap, } \\
\text { materi dicatat cukup lengkap, } \\
\text { tulisan cukup jelas, indah }\end{array}$ & \\
\hline 4 & Kurang & $\begin{array}{l}\text { Peta pikiran kurang lengkap, } \\
\text { kurang logis, kurang jelas, } \\
\text { kurang bisa dibaca, kurang } \\
\text { indah }\end{array}$ & \\
\hline
\end{tabular}

Kriteria keberhasilan ditentukan besarnya persentase kualitas catatan yang dibuat Peserta didik pada level sangat baik. Apabila kualitas catatan sangat baik berjumlah $75 \%$ maka tindakan dikatakan sudah berhasil. Sebaliknya kualitas sangat baik dan baik berjumlah $(<75 \%)$ maka tindakan dikatakan belum berhasil, lebih jelasnya dapat dilihat melalui tabel berikut ini.

Tabel 5. Tabel Kriteria keberhasilan tindakan

\begin{tabular}{|l|l|l|}
\hline No & $\begin{array}{l}\text { Kriteria } \\
\text { keberhasilan }\end{array}$ & Keterangan \\
\hline 1 & Berhasil & $\begin{array}{l}\text { Kualitas catatan sangat baik dan baik } \\
\geq 75 \%\end{array}$ \\
\hline 2 & Belum berhasil & $\begin{array}{l}\text { Kualitas catatan sangat baik dan baik } \leq \\
75 \%\end{array}$ \\
\hline
\end{tabular}


Untuk lebih jelasnya bisa dilihat dari tabel berikut:

Tabel 4 kualitas catatan dengan mind mapping di kelas VII.3 SMP N 42 Padang

\begin{tabular}{|c|c|c|}
\hline Kriteria kualitas & Jumlah peserta didik & $\%$ \\
\hline Sangat Baik & 3 & 10 \\
\hline Baik & 7 & 24 \\
\hline Sedang & 4 & 14 \\
\hline Kurang & 15 & 52 \\
\hline
\end{tabular}

Tabel 5. Nilai Siklus 1 peserta didik SMPN 42 Padang

\begin{tabular}{|l|l|l|l|l|l|l|l|}
\hline $\begin{array}{l}\text { N } \\
\text { O }\end{array}$ & JENIS KELAMIN & \multicolumn{6}{|l|}{ PEROLEHAN HASIL BELAJAR } \\
\hline & & $<$ KKM & & $=$ KKM & & $>$ KKM & \\
\hline & & JML & $\%$ & JML & $\%$ & JML & $\%$ \\
\hline & 14 rang laki2 & 7 & 24 & 4 & 14 & 3 & 10 \\
\hline & 15 Perempuan & 5 & 18 & 6 & 21 & 4 & 14 \\
\hline & Jumlah & 12 & 42 & 10 & 35 & 7 & 24 \\
\hline
\end{tabular}

Berdasarkan tabel diatas dapat disimpulkan bahwa:

1. Kecil dari KKM, diketahui dari tabel diatas jumlah peserta didik Laki2 sebanyak 14 orang, ternyata 7 dibawah KKM dengan prosentase $24 \%$ sedangkan peserta didik perempuan dari 15 orang ternyata 5 orang berada dibawah KKM dengan prosentase $18 \%$. Ternyata kemampuan peserta didik perempuan lebih tinggi dibanding siswa laki-laki

2. Sama dengan KKM diketahui dari tabel diatas jumlah peserta didik laki-laki 14 orang sebanyak 4 orang sama dengan KKM dengan prosentase $14 \%$ sedangkan peserta didik perempuan 15 orang sama dengan KKM 6 orang dengan prosentase $21 \%$

3. Diatas dari KKM peserta didik laki-laki yang berjumlah 14 orang terdapat 3 orang peserta didik laki-laki diatas KKM dengan prosentase $10 \%$ sedangkan dari 15 orang peserta didik perempuan terdapat 4 orang peserta didik perempuan diatas KKM dengan prosentase $14 \%$

C. Siklus II

1. Perencanaan

Pada bagian perencanaan ini penulis menyusunan skenario perencanaan sebagai berikut:
A. Penyempurnaan RPP
B. Evaluasi dari pembuatan mind map minggu yang lalu
C. Menyiapkan peta konsep (bagan) 
D. Menyempurnakan instrument seperti menentukan kriteria kuliatas catatan

E. Menyiapkan contoh mind map yang dikerjakan peserta didik minggu sebelumnya

F. Menyiapkan soal ujian UH 1 (ujian akhir siklus)

G. Pembentukan kelompok kerja peserta didik

2. Tindakan

Pada bagian tindakan mencakup 4 kali pertemuan terdiri dari PendahuluaN, Kegiatan inti, dan Penutup.

Kegiatan yang dilakukan adalah melaksanakan proses pembelajaran bersama mitra sebagai kolaborator. Secara rinci kegiatan yang dilaksanakan adalah sebagai berikut:

A. Pendahuluan

1) Guru dan teman kolaborator bersama - sama masuk keruangan kelas.

2) Guru melaksanakan appersepsi tentang materi ajar Kemerdekaan Mengemukakan Pendapat.

3) Peserta didik diminta untuk menceritakan cara-cara yang dilakukan apbila ada yang mau disampaikan secara santun

4) Guru mitra mengamati proses pelajaran yang sedang berlangsung dengan mengisi lembaran pengamatan untuk siswa dan lembaran pengamatan untuk guru

5) Peserta didik ditugaskan untuk mempersiapkan buku catatan dan buku sumber yang berkenaan dengan materi pembelajaran

6) Guru menyampaikan orientasi umum tentang materi dan manfaat dari mempelajari materi Kemerdekaan Mengemukakan Pendapat.

7) Guru menyampaikan tujuan pembelajaran serta manfaat pembelajaran tentang Materi Kemerdekaan Mengemukakan Pendapat.

B. Kegiatan Inti

1) Mengkondisikan untuk duduk berkelompok

2) Peserta didik diberi informasi tentang materi pembelajaran

3) Peserta didik ditugaskan menyiapkan buku catatan dan buku sumber

4) Peserta didik di beri informasi tentang materi kerja kelompok yang harus sama dengan anggota kelompok lainnya.

5) Peserta didik diberi informasi dan teknik mencatat menggunakan peta pikiran 
6) Semua peserta didik dalam kelompok diminta mencatat materi berdasarkan konsep peta pikiran dengan cara berdiskusi

7) Peserta didik diminta membuat lingkaran di tengah kertas dan di dalam lingkaran ditulis gagasan utama yang sedang dibicarakan

8) Ketua kelompok diminta untuk memberi arahan pada anggota dalam menyimpulkan materi dan dibuat berbentuk mind map

9) Peserta didik diminta menambahkan sebuah cabang pada sisi lingkaran untuk tiap point kunci dari gagasan utama dianjurkan menggunakan pensil/balpoin warna -warni

10) Peserta didik diminta menulis kata kunci pada setiap cabang dari gagasan utama

11) Peserta didik diminta menulis gagasan penting pada setiap cabang.

12) Peserta didik diminta membuat cabang berikut pada setiap cabang dengan selalu membaca materi pembelajaran

13) Ketua kelompok mencek kembali mind map yang sudah dibuat oleh anggota kelompoknya

\section{Pengamatan}

Pengamatan dalam penelitian ini dilakukan oleh teman sejawat yang mengajar mata pelajaran IPS karena guru PKn satu orang di SMPN 42 Padang. Pada tahap observasi, guru bersama teman kolaborator mengamati tingkah laku peserta didik .Pengamatan ditujukan untuk memperoleh data tentang apakah peserta didik membuat peta pikiran ketika mencatat materi pelajaran. Kalau ada seberapa banyak yang melakukannya, apakah semua anggota kelompok bekerja dalam membuat mind map. Apakah ketua kelompok senantiasa memberikan arahan pada anggota kelompok dalam membuat mind map. Apakah peserta didik membuat kesimpulan di akhir proses pembelajaran. Apakah peserta didik merasa terbantu. Kalau ya, seberapa banyak, apakah peserta didik merasa catatan lebih lengkap dan mudah dipahami. Kalau ya seberapa banyak. Dan apakah peserta didik memahami semua materi yang diberikan kalau ya seberapa banyak.

4. Refleksi

Pada tahap ini guru bersama teman kolaborator berdialog mendiskusikan hasil pengamatan, megevaluasi keberhasilan yang dicapai dan permasalahan ditemui dalam siklus 1 . Hasil refleksi itu dijadikan sebagai dasar landasan untuk memperbaiki kelamahan kelemahan yang masih ditemui untuk pembelajaran berikutnya. Keberhasilan tindakan dapat diketahui melalui catatan yang dibuat siswa. Kualitas catatan dilihat dari beberapa kriteria melalui rubrik pensekoran (scoring) rubriks sebagaimana tabel berikut ini. 
Tabel 6. Kualitas catatan siklus 2 di kelas VII.3 SMP N 42 Padang

\begin{tabular}{|c|c|c|}
\hline Kriteria kualitas & Jumlah peserta didik & $\%$ \\
\hline Sangat Baik & 6 & 21 \\
\hline Baik & 8 & 28 \\
\hline Sedang & 5 & 17 \\
\hline Kurang & 10 & 34 \\
\hline
\end{tabular}

Tabel 7. Nilai Siklus 2 peserta didik SMPN 42 Padang

\begin{tabular}{|l|l|l|l|l|l|l|l|}
\hline $\begin{array}{l}\text { N } \\
\text { O }\end{array}$ & JENIS KELAMIN & \multicolumn{6}{l|}{ PEROLEHAN HASIL BELAJAR } \\
\hline & & $<$ KKM & & $=$ KKM & & $>$ KKM & \\
\hline & & JML & $\%$ & JML & $\%$ & JML & $\%$ \\
\hline & 14 orang laki-laki & 6 & 21 & 6 & 21 & 3 & 10 \\
\hline & 15 Perempuan & 3 & 10 & 4 & 14 & 7 & 24 \\
\hline & Jumlah & 9 & 31 & 10 & 35 & 10 & 34 \\
\hline
\end{tabular}

\section{Pembahasan}

Pada bagian ini penulis akan menyampaikan hasil pelaksanaan tindakan peningkatan hasil belajar melalui cara mencatat dengan mind mapping

Sebagai gambaran umum mulai dari studi awal bergerak ke siklus 1 dan lebih sempurna pada siklus II. Untuk lebih jelasnya dapat pada grafik berikut:

Tabel 8. Peningkatan Kualitas catatan melalui tekhnik Mind Mapping

\begin{tabular}{|l|l|l|l|l|}
\hline & $\begin{array}{l}\text { Sangat } \\
\text { baik }\end{array}$ & Baik & Sedang & Kurang \\
\hline $\begin{array}{l}\text { Kondisi } \\
\text { Awal }\end{array}$ & 2 & 3 & 6 & 18 \\
\hline Siklus 1 & 3 & 7 & 4 & 15 \\
\hline Siklus 2 & 6 & 8 & 5 & 10 \\
\hline
\end{tabular}

Tabel 9. Peningkatan nilai peserta didik melalui Mind Mapping

\begin{tabular}{|l|l|l|l|}
\hline & $>$ KKM & $=$ KKM & $<$ KKM \\
\hline $\begin{array}{l}\text { Kondisi } \\
\text { Awal }\end{array}$ & 5 & 6 & 18 \\
\hline Siklus 1 & 7 & 10 & 12 \\
\hline Siklus 2 & 10 & 10 & 9 \\
\hline
\end{tabular}

Berdasarkan tabel tentang kondisi hasil belajar peserta didik mulai kondisi awal peserta didik, siklus satu sampai siklus dua mengalami 
peningkatan. Kondisi awal peserta didik dapat dilihat sebanyak 5 orang nilainya berada diatas KKM mengalami peningkatan pada siklus satu menjadi 7 orang dan siklus dua meningkat menjadi 10 orang. Sedangkan nilai peserta didik pada kondisi awal yang sama dengan KKM sebanyak 6 orang, mengalami peningkatan pada siklus satu menjadi 10 orang dan siklus dua meningkat menjadi 12 orang. Selanjutnya nilai peserta didik pada kondisi awal yang sama dengan KKM sebanyak 6 orang, mengalami peningkatan pada siklus satu menjadi 10 orang dan siklus dua meningkat menjadi 12 orang. Dari perbandingan yang telah digambarkan diatas ternyata ada peningkatan hasil belajar setelah peserta didik membuat catatan dengan mind mapping. Selama ini buku catatan yang mereka miliki cendrung hanya sebatas judulnya saja atau sebatas catatan yang didiktekan guru. Sehingga disaat guru meminta syarat ulangan harus mengumpulkan catatan sebagian besar dari mereka tidak mempunyai catatan materi yang akan diuji. Mind Mapping dapat membuat mereka lebih senang membaca dan mencatat karena lebih efektif, efesien dan lebih jelas materi yang akan dipelajari.

\section{PENUTUP}

Kesimpulan

Berdasarkan analisa data, hasil pengamatan, serta hasil catatan peserta didik selama proses pembelajaran dapat diambil kesimpulan bahwa cara mencatat dengan Mind Mapping dalam pembelajaran PPKN dapat:

1. Menumbuhkan keinginan peserta didik untuk membaca lebih banyak karena ingin menentukan pokok materi yang dibuat dalam bentuk Mind Mapping.

2. Memacu kemampuan peserta didik untuk mencatat dan menyimpulkan

3. Meningkatkan hasil belajar peserta didik karena mereka sudah mau membaca.

4. Menumbuhkan kreafitas siswa dalam membuat catatan yang jelas, indah dan menarik.

Saran

1. Hasil belajar yang maksimal dapat tercapai apabila peserta dapat belajar kembali dirumah melalui bacaan -bacaan penunjang.

2. Kemauan membaca dapat ditumbuhkan apabila peserta didik membuat catatan yang simpel, jelas serta indah tanpa mengurangi materi pokok dari bacaan tersebut.

3. Saran kepada guru sesama bidang studi dan juga guru bidang studi lain agar mau menerapkan Mind Mapping dalam mencatat materi ajar. 


\section{DAFTAR KEPUSTAKAAN}

Asri Budiningsih, Asri, 2004, Pembelajaran Moral, Jakarta :Rineka Cipta.

BNSP, Direktorat Pembinaan SMP Ditjen Mandikdasmen Depdiknas, 2006, Contoh/model Silabus Mata Pelajaran Pendidikan Kewarganegaraan, Jakarta: Depdiknas.

Buzan, Tony.2002. Gunakan Kepala Anda, Teknik Berpikir, Belajar dan Membangunkan Otak. PT Dela Pratasa, Jakarta

Depdikbud, 2014, Buku Guru Pendidikan Pancasila dan kewarganegaraan.

Hamalik oemar. 2004. Proses Belajar Mengajar. Bumi Aksara, Jakarta

Munandar, S.C.U. 1992. Mengembangkan Bakat dan Kreatifitas Anak Sekolah. Gramedia, Jakarta

Kasihani, 2006, Penelitian Tindakan Kelas,Malang :Universitas Negeri Malang,

Kunandar, 2007, Guru Profesional, Jakarta: Raja Grafindo Sejahtera.

Marwanti, 2005, Life Skill dalam Pengembangan Kurikulum, Kumpulan Makalah.

Muchlas Samani, 2007, Menggagas Pendidikan Bermakna, Surabaya :SIC.

Prayitno, 2008, Dasar Teori dan Praksis Pedidikan, Padang :Universitas Negeri Padang

Sudjana, nana. 1992. Penelitian Hasil dan Proses Belajar Mengajar. Bumi Aksara

Wina Sanjaya, 2007, Strategi Belajar Mengajar, Jakarta :Rienneka 